\title{
LIFE CYCLE AND GENETIC DIVERSITY OF WILLOW RUSTS (Melampsora spp.) IN EUROPE
}

\author{
Joanna Ciszewska-Marciniak, Małgorzata Jędryczka \\ Institute of Plant Genetics, Polish Academy of Sciences, Poznań, Poland \\ e-mail: jcis@igr.poznan.pl
}

Received: 19.11.2010

\begin{abstract}
The paper is a review of classical and recent studies on willow rusts in Europe, with special reference to short rotation coppice willows used for biomass production, such as common osier willow (Salix viminalis L.). The review presents the taxonomic classification of rust fungi from the genus Melampsora spp. We present a list of telial hosts (genus Salix) as well as aecial hosts for different rust species. The life cycle of this fungal pathogen is described in detail from the epidemiological and genetic point of view. The DNA polymorphism of $M$. lariciepitea, the rust species most responsible for severe yield losses of plant biomass, is characterised based on RAPD, AFLP and RFLP-PCR methods.
\end{abstract}

Key words: willow, Salix sp., rust, Melampsora spp., life cycle, genetic diversity, short rotation coppice

\section{INTRODUCTION}

The leaf rust, caused by Melampsora spp., is the most widespread and frequent disease of biomass willows (Salix), planted for renewable energy, in many parts of Europe (P e i et. al. 1999; S a mils, 2001; Mc Cracken and Dawson, 2003; Rönnberg-Wästljung et al. 2008; Przyborowski and Sulima, 2010). It can defoliate willows and predisposes them to other diseases. In extreme cases, it can reduce yield as much as $40 \%$ (P a rke r et. al. 1993). The willow rust, one of the most important limiting factors for biomass productivity, is well established in the UK, and all countries of Western Europe - especially in Sweden where willow biomass production fields are frequent. The fungi of the genus Melampsora are damaging agents for willows in Poland (R e m le in - S t a r o s t a, 2007; J edryczka et. al. 2008). As the green energy is projected to make an important contribution to the future energy (S zczukowski et al. 2005; Trybush et al. 2008), the study of its pathogens is regarded as significant.

\section{CLASSIFICATION OF RUST FUNGI}

The rust fungi belong to the class Pucciniomycetes and the order Pucciniales. They contain about 7,000 species (W e b ster and W e ber, 2007), which are grouped in more than 100 genera $(\mathrm{Cum} \mathrm{mins}$ and H i r at s u ka, 1983; Ono and Aime, 2006). The popular name "rust fungi" refers to the reddish - brown colour of urediniospores which are produced in dense pustules on the host plant surface (leaf or stem), giving them a "rusted" appearance.

The rust fungi are unique in many aspects. They are biotrophs, i.e., they can thrive only on the living tissue of plants. Their life cycle is complex, consisting of five spore stages (Fig. 1). They are either heteroecious or autoecious. Heteroecoius species infect two plant hosts which are taxonomically unrelated to each other. Autoecious species, on the other hand, complete their life cycle on the same plant host. A significant feature of these fungal species is their host specificity, i.e., a specific group of rust is capable of infecting a certain range of plant species ( $\mathrm{P} \mathrm{e}$ i et al. 2005).

The rust fungi cause diseases on a wide range of plant species, including trees (e.g., willow, poplar, pine, apple, coffee), cereals (e.g., wheat, oats, barley), vegetables (e.g., bean, asparagus), other field crops (e.g., cotton, soybean), and ornamentals (e.g., carnation, chrysanthemum, snapdragon) (A g ri o s, 2005).

The taxonomy of the rust fungi bases on teliospore morphology, however it has been changing throughout the years. At first, four families were distinguished within the order Uredinales (now: Pucciniales). Later, the number of families was reduced to two: 
Melampsoraceae and Pucciniaceae. C u m mins and H ir a t s uka $(1983,2003)$ proposed a 13- to 14-family system. In their system, only the genus Melampsora is included in the family Melampsoraceae.

\section{TAXONOMY OF WILLOW RUST}

The genus Melampsora was established by Castagne in 1843 (cited by Pe i, 2005). The main characteristic of the genus Melampsora is the formation of a subepidermal crust of sessile, single-celled teliospores, which are visible as black spots on the host's leaf surface (gr. melas - black, psora - scab). The genus Melampsora contains 80-100 species and more than half have been described on Salicaceae. Of the 51 species introduced by Sydow and Sydow (1915), 10 were found on poplars (Populus) and 22 on willows (Salix), both belonging to Salicaceae (P e i, 2005). The most of Melampsora species causing willow and poplar rusts are heteroecious. Heteroecious rust species alternate usually on conifers, but also on dicotyledonous and monocotyledonous plants ( $\mathrm{Pe}$ i, 2005). Alternate hosts for the genus Melampsora fungi have been described by G ä u m m a n (1959), and they are as follows: Abies, Allium, Euonymus, Larix, Ribes, Saxifraga, Viola, and some species of Orchidaceae. The majority of autoecious fungi of Melampsora spp. occur on dicotyledonous plants (e.g. Euphorbiaceae and Linaceae) ( $\mathrm{P} \mathrm{e} \mathrm{i} \mathrm{et} \mathrm{al.} \mathrm{2005),} \mathrm{and} \mathrm{there} \mathrm{is}$ one autoecious species, $M$. amygdalinae Kleb., which occurs on willow plants (Sydow and Sydow, 1915; G ä u m m a n , 1959). It was proved that the occurrence of an alternate host adjacent to the primary willow host caused earlier and more severe rust attacks (S a mils et al. 2001b).

The taxonomy of fungal species belonging to Melampsora spp. is unclear. Within willow rust species, special forms and pathotypes can occur, each capable of infecting certain group of willow plants ( $\mathrm{P} \mathrm{e} \mathrm{i}$ et al. 1996; S a mils et al. 2003). Moreover, the occurrence of these special forms and pathotypes may vary between geographical regions ( $\mathrm{Pe} i$ et al. 1999). Many rust species were described in the late $19^{\text {th }}$ to early $20^{\text {th }}$ century and they were established based on their morphology, alternate host and the telial host range (G ä u m m a n, 1959; L e p p i k, 1972; S a vi le, 1976; Cummins and Hiratsuka, 2003). The fact that host ranges of different rust species often overlap and that these species are indistinguishable in morphology, causes many difficulties in proper identification of Melampsora species. G ä u m m a n (1959) proposed a taxonomic system that regards rust fungi with different alternate hosts as distinct species. $\mathrm{Hy}$ 1 a $\mathrm{d}$ e $\mathrm{r}$ et al. (1953) recognized Melampsora epitea Thüm. as a complex species to include species of similar morphology. Another system created by W i 1 s o n and He n d e r s o n (1966), based on Hylander's system, gathers various species and races that are similar in morphology, but alternate on hosts of different genera, into one collective species $-M$. epitea Thüm.

\section{HOST GENUS SALIX}

Willows (Salix L.) belong to the family of Salicaceae. The genus Salix is one of the largest in the northern hemisphere, as regards woody plants. The number of described willow species varies between $300-500$ worldwide, with 270 species in China, 120 in the former Soviet Union, over 100 in North America, and some 65 willow species in Europe (A rg u s, 1997; P e i, 2005). Salix species are insect-pollinated dioecious plants, which hybridize relatively easily. This is the most probable reason of taxonomic difficulties. Willows are grouped into subgenera, such as $V e-$ trix (shrub willows), Chamaetia (dwarf willows), and Salix (tree willows). As far as there is an agreement among taxonomists on the recognition of species typically forming trees (Salix), the classification of willows of the subgenera Vetrix and Chamaetia is problematical, because they differ widely in their morphology. Almost all willows planted for biomass production belong to the subgenus Vetrix, which consists of 1520 species (P e i et al. 1996).

\section{LIFE CYCLE}

The life cycle of the fungi belonging to the genus Melamspora is complex, including five different spore stages, i.e., basidiospores, spermatia, aeciospores, urediniospores, and teliospores (Fig. 1). It is probably the most complex life cycle found anywhere in nature (W e bster and W e ber, 2007).

The spread of rust on a willow host takes place during the summer and includes several repeated cycles of clonal propagation of urediniospores. The urediniospores are capable to produce the next generation in 6-7 days ( $\mathrm{Pe}$ i et. al. 1996). The fungus develops teliospores in late summer and autumn, and overwinters on fallen willow leaves. In the spring, they germinate to produce basidiospores which are capable to infect the alternate host - larch (Larix), on which asexual reproduction takes place. Fertilization between spermatia and receptive hyphae results in the formation of recombinant aeciospores. The aeciospores infect new willow leaves in the early summer, and in this way the life cycle is completed. The spore stages differ, according to their nuclear condition. The basidiospores and spermatia are monocarytotic, containing a single haploid nucleus $(1 \mathrm{n})$, while aeciospores and urediniospores are dikaryotic, having two haploid nuclei $(1 \mathrm{n}+1 \mathrm{n})$. The teliospores are dikaryotic in the early phase, but later the two nuclei fuse (2n) forming a diploid cell (Fig. 2). 


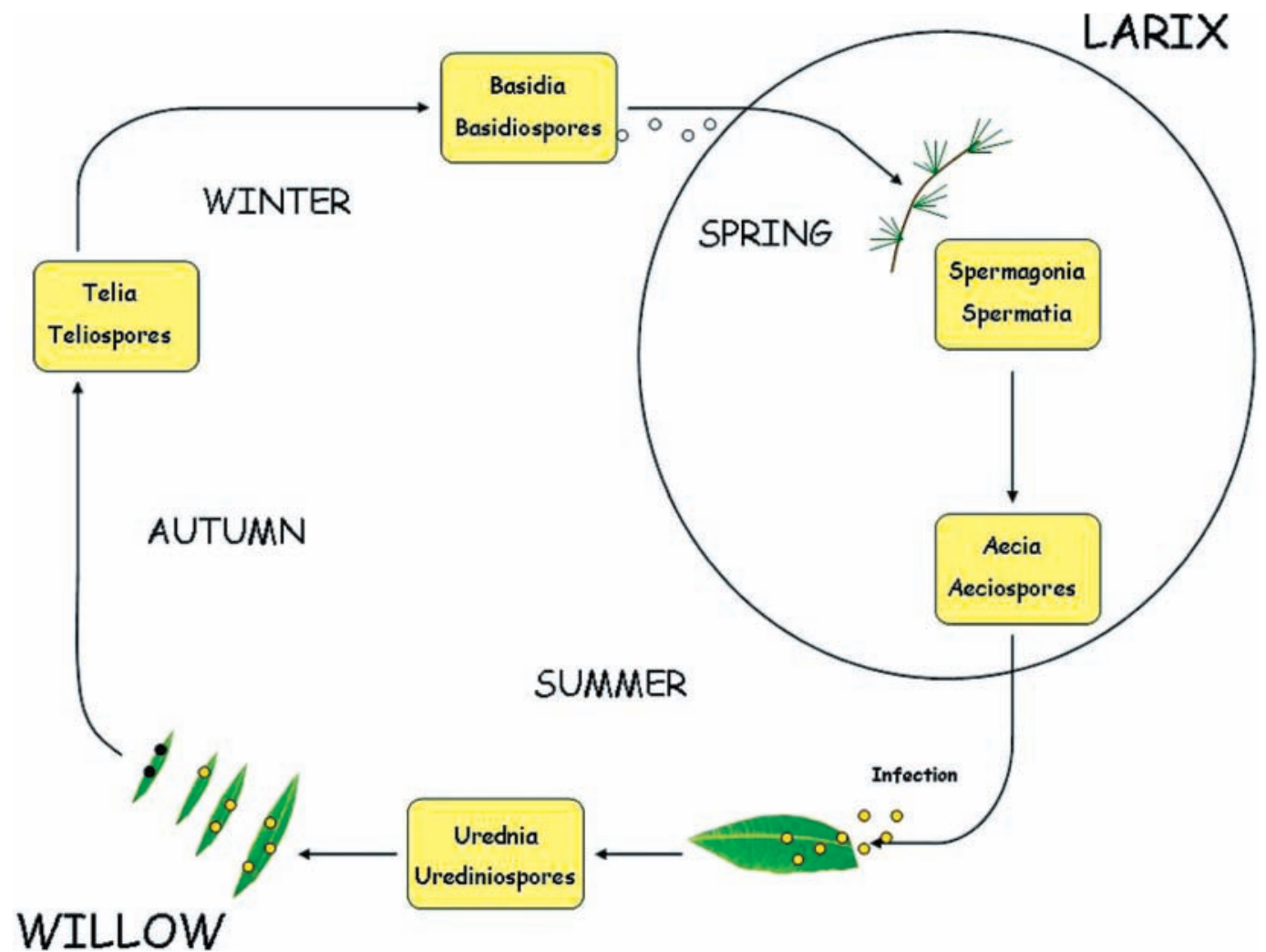

Fig. 1. The life cycle of Melampsora spp.

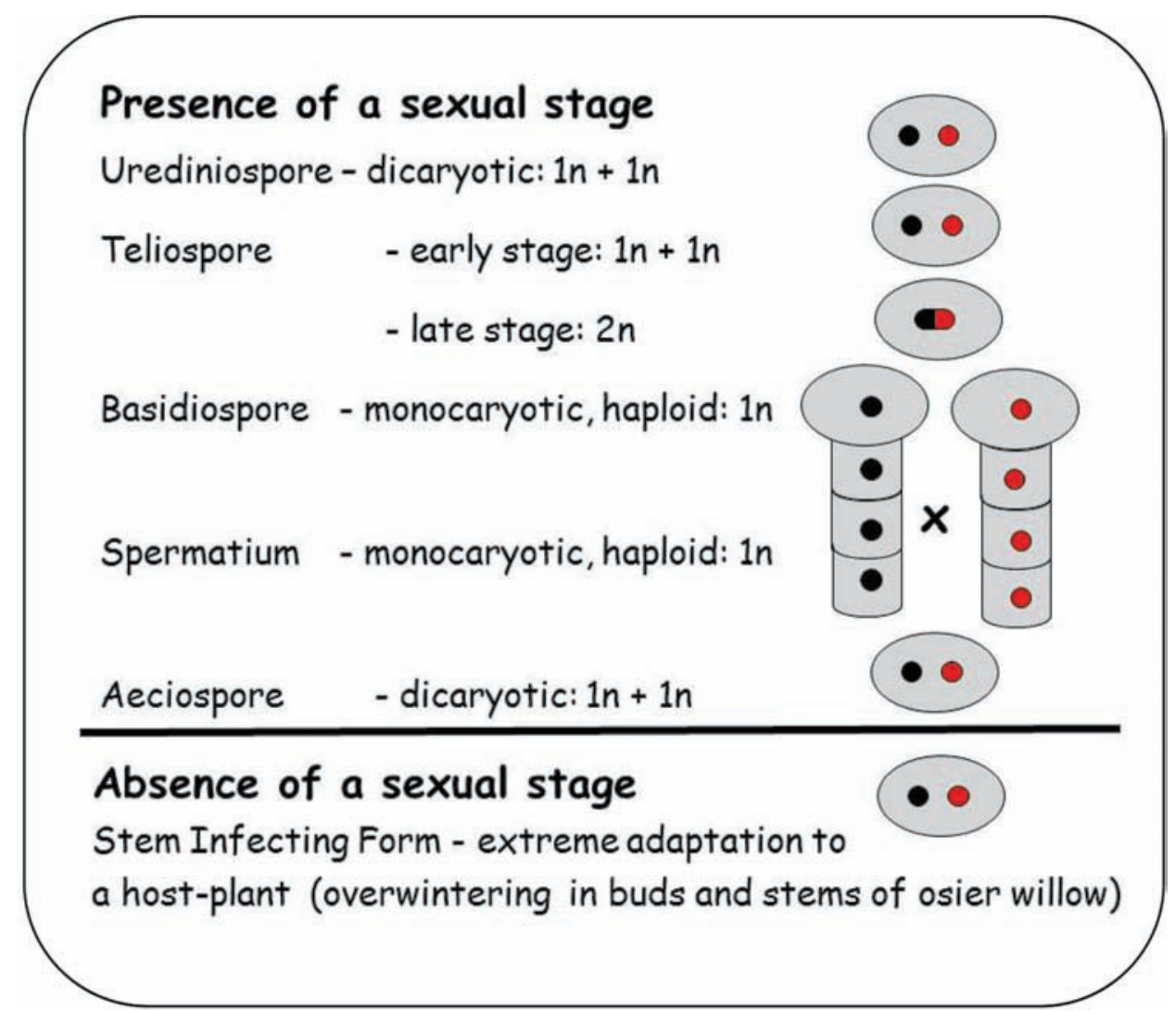

Fig. 2. Nuclei of Melampsora spp. at different stages of the fungus life cycle 


\section{RUSTS SPECIES ON WILLOW PLANTS}

Of all willow species, the most popular in biomass plantations is common osier willow $S$. viminalis and its numerous interspecific hybrids. S z c z u k o w $\mathrm{ski}$ et al. (2004) mention two other willow species that can be grown for energy production, considering their quick biomass increase, i.e. S. amygdalina (syn. S. triandra) and $S$. dascyclados (syn. S. burjatica). Besides, there are some other important species of willows that can be successfully planted in short-rotation coppice, i.e. S. caprea, S. cinerea, S. daphnoides and S. purpurea.

There are many species of Melampsora spp. that were described on willows in Europe (Table 1). Of the 34 rust species identified worldwide, 18 were described on willow plants on the Old Continent. By now, the predominant leaf rust in willow plantations has been $M$. larici - epitea (the larch alternating group of $M$. epitea var. epitea) (P e i et al. 1993). Within M. larici - epitea, six formae speciales have been recognized in Europe: f.sp. larici - epitea typica Kleb., f.sp. larici - daphnoides Kleb., f.sp. larici-nigricantis Schneid., f.sp. larici - purpurea Schneid., f.sp. larici - retusae Fischer, f.sp. larici - reticulate (S y d ow and $\mathrm{S} \mathrm{y-}$ d ow, 1915; G ä u m m a n, 1959). M. larici-epitea was observed on several willow species, i.e. S. aurita, S. caprea, S. cinerea, S. daphnoides, S. dascyclados, $S$. purpurea, $S$. triandra, and $S$. viminalis, but only one of six special forms was identified as capable to infect osier willow (S. viminalis) - f.sp. larici - epitea typica. Simultaneously, f.sp. larici - epitea typica was found on other willow species (S. aurita, S. caprea, S. cinerea) (cited by Pe i, 2005). Recent data obtained in Poland also confirm that $M$. larici - epitea f.sp. typica is a dominant pathogen of $S$. viminalis in the country (C is zew s ka-Marciniak et al. 2010). The willow species infected by other special forms of M. larici - epitea are listed in Table 1. M. ribesii - viminalis Kleb. and Stem Infecting Form (SIF) were observed on common osier willows in the UK (P e i, 2005). The first one alternates on Ribes spp. and the second one is deprived of a sexual stage in its life cycle (P e i et al. 1993, 1995). Within Melampsora species, mentioned in Table 1, M. amygdalinae Kleb. is the only one autoecious willow rust (no alternate host is required).

Table 1

The list of Melampsora species reported on the most popular willows in Europe, including these used for biomass production*

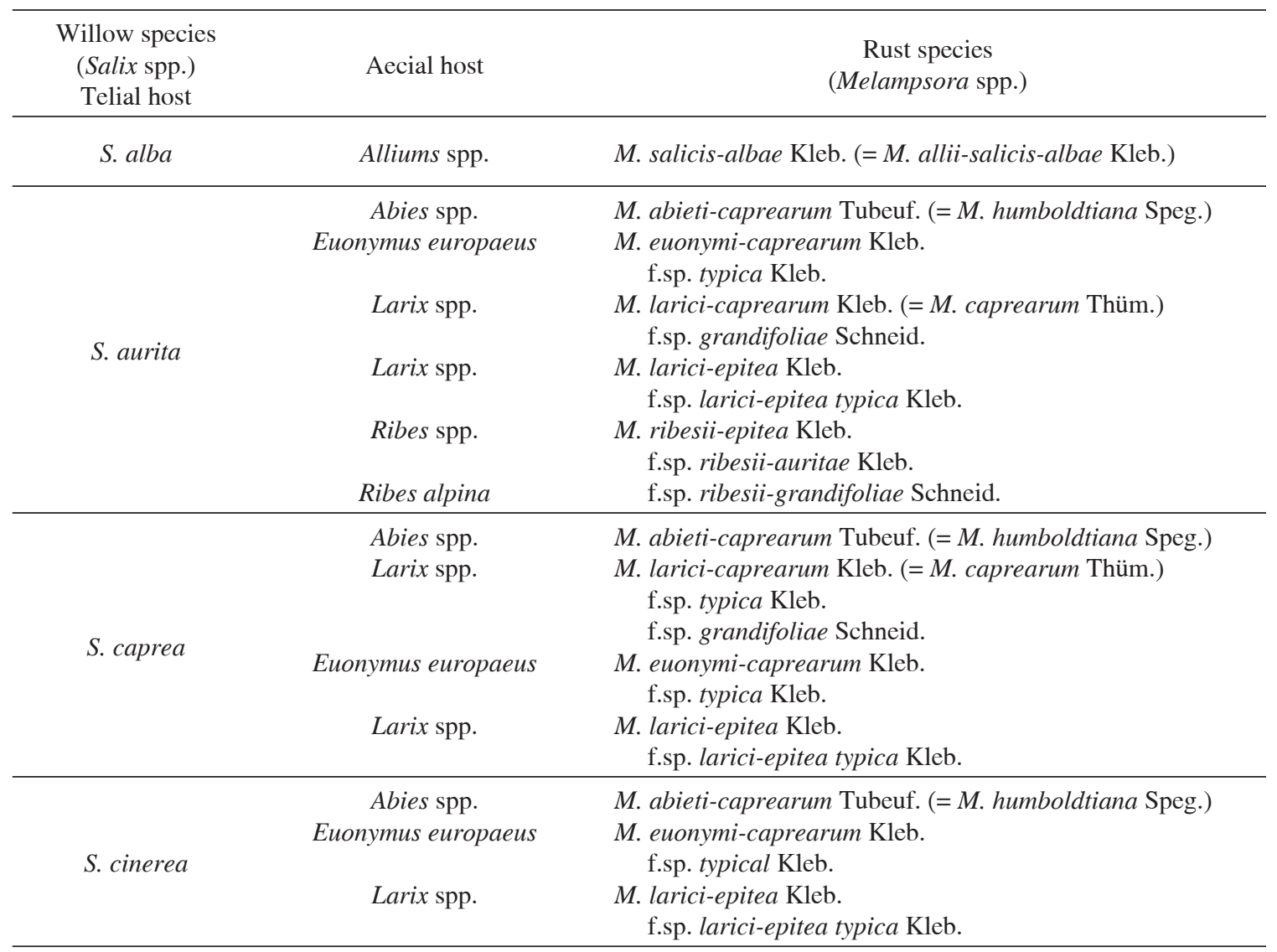




\begin{tabular}{|c|c|c|}
\hline S. daphnoides & Larix spp. & $\begin{array}{l}\text { M. larici-epitea Kleb. } \\
\text { f. sp. larici-daphnoides Kleb. } \\
\text { f. sp. larici-purpureae Schneid. }\end{array}$ \\
\hline S. dascyclados & Larix spp. & $\begin{array}{l}\text { M. larici-epitea Kleb. } \\
\text { f.sp. larici-retusae Fischer }\end{array}$ \\
\hline S. fragilis & $\begin{array}{l}\text { Alliums spp. } \\
\text { Galanthus nivalis }\end{array}$ & $\begin{array}{l}\text { M. allii-fragilis Kleb. } \\
\text { M. galanthi-fragilis Kleb. }\end{array}$ \\
\hline S. purpurea & $\begin{array}{l}\text { Abies spp. } \\
\text { Larix spp. } \\
\text { Ribes spp. }\end{array}$ & $\begin{array}{l}\text { M. abieti-caprearum Tubeuf. (= M. humboldtiana Speg.) } \\
\text { M. larici-epitea Kleb. } \\
\text { f.sp. larici-purpureae Schneid. } \\
\text { M. ribesi-purpureae Kleb. }\end{array}$ \\
\hline S. triandra & $\begin{array}{l}\text { S. triandra, } \\
\text { S. pentandra }\end{array}$ & M. amygdalinae Kleb. \\
\hline S. viminalis & $\begin{array}{l}\text { Larix spp. } \\
\text { Ribes spp. } \\
\text { No known aecial stage }\end{array}$ & $\begin{array}{l}\text { M. larici-epitea Kleb. } \\
\quad \text { f.sp. larici-epitea typica Kleb. } \\
\text { M. ribesi-viminalis Kleb. } \\
\text { Stem-infecting form }\end{array}$ \\
\hline
\end{tabular}

\section{GENETIC DIVERSITY IN POPULATIONS OF MELAMPSORA LARICI - EPITEA}

The studies of genetic diversity of plants or animals were possible for a long time before the discovery of nucleic acid structure and DNA/RNA testing methods. However, for microscopic fungi, especially biotrophs, such as rusts, indirect phenotypic observations of their mycelium and fruiting bodies had limited application. The development of Polymerase Chain Reaction method by Mullis and Faloon a (1987) made possible to amplify specific DNA sequences, which brought in turn the development of numerous techniques to study its diversity in size and nucleotide sequences. An important region studied by numerous researchers was the Internal Transcribed Spacer (ITS) containing two variable non-coding regions nested within the rDNA repeats between the highly conserved small and large subunits of rRNA genes (W hite et al. 1990). Numerous studies have shown that the ITS region was highly variable among fungal species, whereas - with some exceptions - the intraspecific variation was low. The first primers designed to amplify the ITS region were nonspecific, however Gardes and Burns (1993) - followed by other researchers - designed primers with enhanced specificity for basidiomycetes, allowing to study mycorrhizal fungi and rusts. The Restriction Fragment Length Polymorphism (PCR-RFLP) analysis of the ITS region, allowing to divide this region into smaller fragments, using the restriction enzymes, allowed to differentiate some Melampsora rust species originating from willows into ten groups, with six groups being species-specific ( $\mathrm{Nakamura}$ et al. 1998). The isolates of $M$. epitea were separated into three RFLP types, suggesting that it is a complex composed of at least three distinct species or sub-species.

One of the popular methods to study the DNA polymorphism is the use of Random Amplified Polymorphic DNA, which does not demand any knowledge on the sequence of the studied DNA fragment. Using this method, it was possible to distinct between stem- and leaf-infecting forms of Melampsora rust on osier willow ( $\mathrm{Pe}$ i et al. 1997). Another widely used method allowing to study the DNA polymorphism of M. larici-epitea was Amplified Fragment Length Polymorphism. The method allowed to find distinct DNA profiles in morphologically similar isolates ( $\mathrm{S}$ a $\mathrm{m}$ i l s et al. 2002). Moreover, AFLP helped to assess the genetic structure of its populations in different countries. The method revealed high levels of gene and genotypic variation in Swedish populations ( $\mathrm{S}$ a mils et al. 2001a). High genetic variation was observed even within isolates originating from one field. The result suggested the importance of sexual reproduction in rust fungi present in this region. However, no differences in genetic composition were found in M. larici-epitea populations obtained from monoclonal and mixed willow fields (S a mils et al. 2003). Extremely high gene and genotypic diversity observed in Sweden contrasted with low DNA polymorphism of isolates originating from Northern Ireland $(\mathrm{S}$ a $\mathrm{m}$ i $1 \mathrm{~s}$ et al. 2001b).

In 2006 fifteen microsatellite loci were described in the poplar rust fungus, M. larici-populina, and five related species (B a rrè s et al. 2006), but they have not been found in M. larici-epitea by now. 


\section{REFERENCES}

Agrios G.N., 2005. Plant pathology, 5th edn. Elsevier Academic Press, New York

Argu s G.W., 1997. Infrageneric classification of Salix (Salicaceae) in the New World. Systematic Botany Monographs, vol. 52. The American Society of Plant Taxonomists, Michigan.

Barres B., Dutech C., Andrieus A., Caron H., Pinon J., Frey P., 2006. Isolation and characterization of 15 microsatellite loci in the poplar rust fungus, Melampsora larici-populina, and cross-amplification in related species. Molecular Ecology Notes, 6: 60-64.

Ciszewska-Marciniak J., Jędryczka M., Jeżowski S., Przyborowski J., Wojciechowicz K., Zenkteler E., 2010. Morphology of uredinia and urediniospores of the fungus Melampsora larici - epitea Kleb. A damaging pathogen of common osier (Salix viminalis L.) in Poland. Acta Agrobot. 63 (2): 117-125.

Cummins G.B., Hiratsuka Y., 1983. Illustrated Genera of Rust Fungi, revised edn. APS Press, St Paul, Minnesota.

Cummins G.B., Hiratsuka Y., 2003. Illustrated Genera of Rust Fungi, 3rd edn. APS Press, St Paul, Minnesota.

Gardes M., Bruns T.D., 1993. ITS primers with enhanced specificity for basidiomycetes - application to the identification of mycorrhizae and rusts. Molec. Mycol. 2:113-118.

Gäumman E., 1959. Die Rostpilze Miteleuropas. Beitr. Kryptogamenflora Schwiez. 12.

Hylander N., Jøstad I., Nanfeldt J.A., 1953. Enumeratio Uredinearum Scandinavicarum. Opera Botanica, 1: 1-102.

Jędryczka M., Ciszewska-Marciniak J., Przyborowski J., 2008. The search for genetic sources of willow resistance to rust (Melampsora epitea), Phytopathol. Pol. 49: 5-19.

Leppik E.E., 1972. Evolutionary specialization of rust fungi (Uredinales) in the Leguminosae. Ann. Botanici Fennici 9: 135-148.

McCracken A.R., Daws on W.M., 2003. Rust disease (Melampsora epitea) of willow (Salix spp.) grown as short rotation coppice (SRC) in inter- and intra-species mixture. Ann.Appl.Biol. 143: 381-393.

Mullis K.B., Faloona F.A., 1987. Specific synthesis of DNA in vitro via a polymerase-catalyzed chain reaction. Methods in Enzymology, 155: 335-350.

Nakamura H., Kaneko S., Yamaoka Y., Kakis hima M., 1998. Differentiation of Melampsora rust species on willows in Japan using PCR-RFLP analysis of ITS regions of ribosomal DNA. Mycoscience, 39: 105-113.

Ono Y., A i me M.C., 2006. Recent advances in rust systematics. Mycoscience, 47: 111.

Parker S.R., Royle D.J., Hunter T., 1993. Impact of Melampsora rust on yield of biomass willows.
In abstracts of the $6^{\text {th }}$ International Congress of Plant Pathology, Montreal, Canada, 28 July-6 August 1993. Montreal: 117.

Pei M.H., Royle D.J., Hunter T., 1993. Identity and host alternation of some willow rusts (Melampsora spp.) in England. Mycol. Res. 97: 845-851.

Pei M.H., Royle D.J., Hunter T., 1995. A comparative study of stem- and leaf-infecting forms of Melampsora rust on Salix viminalis in the U.K. Mycol. Res. 99 (3): 357-363.

Pei M.H., Royle D.J., Hunter T., 1996. Pathogenic specialization of Melampsora epitea var. epitea on $\mathrm{Sa}$ lix. Plant Pathology, 45: 679-690.

Pei M.H., Whelan M.J., Halford N.G., Royle D. J., 1997. Distinction between stem- and leaf-infecting froms of Melampsora rust on Salix viminalis using RAPD markers Mycol. Res. 101 (1) : 7-10 (1997)

Pei M.H., Hunter T., Ruiz C., 1999. Occurrence of Melampsora rusts in biomass willow plantations for renewable energy in the United Kingdom. Biomass Bioenergy 17: 153-163.

Pei M.H., Bayon C., Ruiz C., 2005. Phylogenetic position of Melampsora in rust fungi inferred form ribosomal DNA sequences. In: Rust diseases of willow and poplar. CAB Inter., Wallingford, UK.

Pei M.H., 2005. A brief review of Melampsora rusts on Salix. [In]: Rust diseases of willow and poplar. CAB Inter., Wallingford, UK.

Przyborowski J.A., Sulima P., 2010. The analysis of genetic diversity of Salix viminalis genotypes as a potential source of biomass by RAPD markers. Industrial Crops and Products, 31: 395-400.

Remlein-Starosta D., 2007. Choroby roślin energetycznych Diseases of bioenergy crops. Progress in Plant Protection / Postępy w Ochronie Roślin, 47 (4): 351357 (in Polish).

Rönnberg-Wästljung A.C., Samils B., Tsarouhas V., Gullberg U., 2008. Resistance to Melampsora larici-epitea leaf rust in Salix: analyses of quantitative trait loci. J. Appl. Genet. 49, 4: 321-331.

S a mils B ., 2001. Population genetic structure of Melampsora larici-epitea, a willow leaf rust fungus. Agraria 292.

Samils B., Lagercrantz U., Lascoux M., Gu11berg U., 2001a. Genetic structure of Melampsora epitea populations in Swedish Salix viminalis plantations Eur. J. Plant Pathol. 107: 399-409.

Samils B., Stepien V., Lagercrantz U., Lascoux M., Gullberg U., 2001b. Genetic diversity in relation to sexual and asexual reproduction in populations of Melampsora larici-epitea. Eur. J. Plant Pathol. 107: 871-881.

Samils B., Lagercrantz U., Gullberg U., 2002. Genetic relationships among genetically distinct forms of Melampsora larici-epitea and related species based on AFLP data. For. Path. 32: 379-386

Samils B., McCracken A.R., Dawson W.M., Gullberg U., 2003. Host-specific genetic composition of Melampsora larici-epitea populations on two 
Salix viminalis varieties in a mixture trial. Eur.J.Plant Pathol. 109: 183-190.

Savile D.B.O., 1976. Evolution of the rust fungi (Uredinales) as reflected by their ecological problems. Evolutionary Biology 9: 137-207.

Sydow P., Sydow H., 1915. Monographia Uredinearum 3. Bornträger, Leipzig.

Szczukowski S., Tworkowski J., Stolarski M., 2004. Wierzba energetyczna. / Energy willow. Plantpress. Kraków.

Szczukowski S., Stolarski M., Tworkowski J., Przyborowski J., Klasa A., 2005. Productivity of willow coppice plants grown in short rotations. Plant Soil Environ. 51(9): 423-430.

Trybush S., Jahodova S., Macalpine W., Karp A., 2008. A genetic study of Salix germplasm resource reveals new insight into relationships among subgenera, section and species. Bioener. Res. 1: 67-79.

Webster J., Weber W.S., 2007. Introduction to fungi, $3^{\text {rd }}$ edn. Cambridge University Press, New York.

White T.J., Bruns T., Lee S., Taylor J., 1990. Amplification and direct sequencing of fungal ribosomal RNA genes for phylogenetics. In: PCR Protocols: a guide to methods and applications. Ed. by Innis M.A., Gelfand D.H., Sninsky J.J., White T.J. Academic Press, New York: 315-322.

Wils on M., Henderson D.M., 1966. The British Rust Fungi. Cambridge Univeristy Press, Cambridge, UK.

\section{Cykl życiowy i zmienność genetyczna rdzy (Melampsora spp.) na wierzbach w Europie}

\section{Streszczenie}

Publikacja zawiera przegląd najważniejszych, a także najnowszych badań dotyczących rdzy na wierzbach w Europie, ze szczególnym uwzględnieniem wierzb krzewiastych o krótkiej rotacji, takich jak wierzba wiciowa (Salix viminalis L.), stosowanych w celu uzyskania biomasy roślinnej. W pracy przedstawiono listę gatunków rodzaju Melampsora spp., powodujących rdze na wierzbach. Praca zawiera spis wierzb (rodzaj Salix), na których powstają telia oraz różnych gatunków roślin - gospodarzy dla stadium tworzenia ecjów. Z epidemiologicznego i genetycznego punktu widzenia opisano cykl życiowy tych patogenów grzybowych. Zaprezentowano także wyniki badań nad polimorfizmem DNA, charakteryzowanym metodami RAPD, AFLP oraz RFLP-PCR u M. lariciepitea, gatunku rdzy odpowiedzialnego za największe straty plonu biomasy wierzby. 